\title{
Om de sønderjydske Folkeminder.
}

\section{Af August F. Schmidt.}

Det er af Betydning for Lokalhistorikerne, at de er fortrolige med Folkeminderne i det Sogn, som de har taget til Opgave at skildre; ja, der bør i enhver større Sognehistorie være fyldige Oplysninger om Sognets gammeldags Folkeliv, om Bondearbejder, Bygninger, Fester, Højtider, Stedsagn, Tro m. m. Store Mængder af Folkeminder fra alle Danmarks Egne er allerede indsamlede og udgivne i Bøger eller indsendt til vort Folkemindearkiv: Da n sk F o l ke minde sa m l ing ) (Kgl. Bibliotek, København $K$.), oprettet 1904, men der er naturligvis langt igen, inden man tor sige, at det meste danske Folkemindestof er optegnet og bevaret for kommende Slægter. Lokalhistorikere kan derfor udføre en virkelig betydningsfuld kulturhistorisk Gerning ved at indsamle de endnu af gamle Mennesker erindrede få Minder om det Almueliv, der nu for stedse er forsvundet.

Fra Sønderjylland er også optegnet et omfangsrigt folkloristisk Materiale, hvoraf meget findes u trykt i Dansk Folkemindesamling ${ }^{2}$ ). Der bor dog stadig indsamles Folkeminder $i$ denne Landsdel, idet der fra mange Sogne kun findes ganske enkelte optegnelser. Især tiltrænges Indsamling i Haderslev Østeramt, hele Vesteregnen og Mellemslesvig, ganske særlig hvor det danske Sprog er truet eller døende. I de sidste 5-6 År er der imidlertid blevet optegnet

1) A ben for Besagendle daglig Kl. 10--3 undtagen i Juli.

2) I det følgende forkortet til D. F. S. 
slet ikke să fă Folkeminder i Vesteregnen og i Mellemslesvig. En Del af disse Minder er offentliggjort $i$ „Samleren« i Sønderjydsk Månedsskrift (1924ff.), men en ikke ringe Del Optegnelser fra Sognene sydfor Grænsen er sendt til DFS.s Arkiv. Det er især de to Vandrelærere Gustav Lindstrøm og M. P. E jerslev, der har udført et smukt og påskønnelsesværdigt Indsamlingsarbejde ved Siden af leres Lærervirksomhed i Mellenıslesvig.

I DFS. findes det sonderjydske Folkemindemateriale, der er indsamlet siden 1904, under Topografinumrene $3000-3473^{1}$ ). Hvert sønderjydsk Sogn fra Kongeaen til Ejderen har i DFS. sit Nummer indenfor de navnte Tal i samnie Rakkefølge som Sognene i Traps Danmark (forste Udgave 18(i4). Ved en Gennemgang i April 1929 af DFS.s Arkivrækker: 1906/23 (Sagn og Tro, Originaloptegnelser), 1906/24 (Sagn og Tro, Avisudklip), 1906 43 (Fester), 1906/46 (Folkeliv), 1906/47 (Folkeliv, Avisudklip) og E v a l d T a n g K r ist ensens Afskriftsrække af Danske Sagn I-VII, 2. Række (utrykt) ${ }^{2}$ ), viste det sig, at (ler i disse Arkivets Hovedrækker fandtes Folkemindeoptegnelser fra alle Sognene nordfor Grænsen med Undtagèlse af kun folgende tre Sogne: Vilstrup (Haderslev Amt), Højer Landsogn og Skast (Tønder Amt). Fra Mellen- og Sydslesvig var Forhollet selvsagt et noget andet, idet der fra over 100 Sogne mellem vor Sydgrænse og Ejderen slet ingen Optegnelser fandtes i DFS., medens der fra følgende sogne fin des Op-

1) En Fortegnelse over Sognene i det ovigge I)anmark med deres Topografinumre er udgivet i Festskrift til H. F. Feilberg, 1911, 477 ff. Den sonderjyclske Topografi er desvarre ikke trykt.

2) I'a Woels Forlag er pábegynat Idgivelsen af Danske Sagn 2. Rk. (19:8ff.). hvoraf to Bind er udkomnet, da dette skrives. 
tegnelse i DFs.: Øen A m rum, Medelby, Lade l u n d, Søn d e r-L y g u m, K a r l u m, Læk, A v e nt of t, Brarup, Enge, stedesand, K langsbøl, Horsbøl, N e bøl, Da gebøl, H a nved, Valsbøl, Haksted, Vi, Oversø, $S$ iversted, If unkbrarup, Lyksborg, Grumtoft, Sør u p, K v r r, N y k i k e, Eskris, Flens b o g, slesvig med Gottorp, Sønder Brarup, Sa trup, Slesvig, st. Michaelis Landsogn (I s t e d), Ha d d e by (herunder Dannevirke), h r op, Süd erstapel, Frederikss tad, Frisl a nd, Fjolde, H joldelund, Langhorn, Borde lum, Nordstrand (Ode n b üll), Witzwort (Ejdersted), E ckernfor de, Dän ischenhage $n$, Rendsborg Kristkirkes Sog $n^{1}$ ).

I DFS. fincles der forskellige andre Samlinger af sonderjydske Folkeminder end dem, der er indgâet i den i 1906 påbegyndte store Samling 1906/23 o. s. v., som udgør Arkivets Hovedbestanddel af dansk Folklore. Således findes der i H. F. F e il bergs Samling en stor Bunke Optegnelser, benævnt "Pillemar", senut Feilberg fra Lærer M. J. Sk ov i Øster-Abolling. Skovs Optegnelser, der indeholder mange Dialektorl, som Feilberg brugte i sin "Jysk Ordbog", og lisange kulturhistoriske oplysninger, benyttede i "Dansk Bondeliv«, burle anvemles samlede i en Bog om Folkelivet i Egnen mellem Ribe og Gram. (I DFS. findes der fornvrigt særlig mange værdifulde Folke-

1, Jer er her slet ikke Tale om, hval der fincles af trykte lolkeminder fra Sonderjylland. I den lokalhistorisk-topografisk-folkloristiske Litteratur kan der jo nieget vel findes Folkeminder fra de tre nordslesvigske som fra de over Hundrede mellem- og sydslesvigske Sogne, der ikke er l'eprasenterede i DFs. Henvisninger til Litteratur fimdes lh. a. i sivend I) a hls og Axel Linvalds "Sonderjylland木 II (1919), 323 ff. og Traps Ilanmark IX (De sunderjydike I andsdele) 1925 ff. 
IIIndeoptegnelser fra Gram Sogn). I "Jysk Ordbog " Bind I (1886-93) S. VII takker Feilberg Lærer Skov ucien at nævne hans Navn, hvad Skov ikke har ønsket. Han underskrev sig i Breve til Feilberg med sit Navn læst bagfra: "Voks«. Det var jo i Fremmedherredømmets Tid. - I DFS. har Hans Pileg a a rd, Lintrup, et Par selvstændige Kapsler, indeholdende en stor Mængde kulturhistorisk set værdifulde Avisudklip, for Størstepartens Vedkommende angående Sonderjylland. Hans Pilegaard har igennem en Arrække samlet Folkeminder i Lintrupegnen ${ }^{1}$ ). For denne Virksomhed blev han i 1929 benådet med Dannebrogsmændenes Hæderstegn. - Til DFS. har Pastor C. L u d vig s e n, nu i Åbenrå, udskrevet det Stof vedrørende Sagn og Folketro, som findes i den gamle alsiske Præst $C h r$. K n u d s e n s Optegnelser om Als' Historie. Chr. Knudsens Optegnelser findes i en Række hândskrevne Hefter i $\mathrm{Ny}$ kgl. Samling 2683 på det kgl. Bibliotek. Det vigtigste Folkemindestof i denne Samling er benyttet i He nrik.Ussings Bog: "Det gamle Als" (1926) og i "Samleren« i Sønderjysk Månedsskrift. - Om Sagn, Tro og Skik vedrørende Fugle findes en Mængde hidtil utrykte sønderjydske Optegnelser i Frederik Lange Grundtvigs Samlinger (se særlig DFS. 1904/34). Af sønderjydske Melodier er nogle få trykt i A. P. B erggreens: "Danske Folkesange" og i "Sprogforeningens Almanak" for 1923 ved $H$. Grüner Nielsen, men flere kan findes blandt Folkemindesamlingens Papirer. En supplerende $\mathrm{Me}$ lodiindsam ling foretoges af $\mathrm{H}$. Grüner Nielsen i Sønderjylland 1909, der optog fonografisk 42

1) Se Hans Pilegaarl og August F. Schmidt: "Fri Lintrup Sogn« (Äbenr'a 1925). 
gamle Melodier. $\left.{ }^{1}\right)$ Udgivelsen af en Sagnsamling omfattende alle sønderjydske Sagn har været påtænkt af Professor A x e l O lrik (død 1917) og Pastor C. L u dvigsen i Abenrå. Forarbejderne til dette Værk er nu deponeret i D. F. S. i Axel Olriks Afdeling. Disse Forarbejder er ikke blot en Afskriftsrække, men indeholder mange originale Bidrag, dels indsamlet af A. Olrik på Rejser 1888-89 og af Ludvigsen i 1904, dels indsendt fra forskellige Sønderjyder som Følge af et Opråb i Flensborg Avis $8 / 81906$. Inddelingen af det forbavsende omfangsrige Sagnstof har været påtænkt omtrent således: Kæmper og Trolde, Kongers og Kæmpers Grave, Landets Udseende og Bebyggelse (Stormflod, Skove, Røvere, Tingsteder, og Galgehøje, forsvundne Landsbyer, Landsbyers Trætte, Vilde Dyr), Slag og Volde (Danevirke, Margrete m. m.), Sorte Død, Valdemarerne, Kristian IV, Kampe i Middelalderens Slutning, Svenskekrigen, Borgsagn (Nørrevold og Søndervold, Borgvolde, Borgfruen på Ris), Herremænds Fejde (Svend Graa, Adelbrand, Hr. Tor), Kristendom (Forste Kristne, Jomfruernes Kirkebygning, Oksernes Kirkeplads, Kirkestenene flytter sig selv, Katolsk Kirkeskik, Forsvundne Kirker, Fattigdom på Præster). Sagn om Præster, Sagn om Bønder, Sagn om Personer og Slægter, Skæmtesagn m. m. ${ }^{2}$ )

Evald Tang Kristensen (død 1929) indsamlede på forskellige Rejser i Sønderjylland en ikke ringe Del Folkeminder af forskellig Art. Kun lidt af dette Stof fik han trykt i sine Bøger. Noget

1) Jfr. Evald Tang Kristensen: "Minder og Oplevelser IV (1928), 378 f. H. Grüner Nielsen i Fortid og Nutid III (1920), $38 \mathrm{og}$ Arbog for Musik 1923 [1924], $79 \mathrm{f}$.

2) Et lille Udvalg af forskellige Sagn fra Sønderjylland er udgivet af $F$. O h r t: "Udvalgte sønderjydske Folkesagn« (1919). 
findes i hans "Jydsk Almueliv" især i dette Værks Tillægsbind I-VI (1900-1905) og andre Steder i hans mange Bøger, men af Sagnene er der ikke trykt ret mange. De findes $i$ den ovennæunte utrykte Samling Sagn, der nu bliver udgivet på Woels Forlag.

I September 1894 rejste Evald Tang Kristensen samimen med H. P. H a n s s e fra et Møde i Askov til Abenrå. Forinden havde E. T. Kr. fået en Del Adresser af Poul B jerge, Askov, på Mænd i Sønderjylland, som han kunde have Udbytte af at komme i Forbindelse med. På denne Rejse besøgte han først Gården Lysholm i Egen Sogn på Als. Her opholdt han sig hos de gæstfri Folk i flere Dage og udspurgte en Del gamle Mennesker i Gårdens Omegn. Han var bl. a. også i Nordborg. Senere foretog han Indsamlinger i Bovlundegnen, var hos J. F a u sbø ls i Branderup Mølle, i Hyrup, Gestrup og i Vellerup og hjemsøgte adskillige gode Meddelere. Degnen N. Kuntz i Sottrup måtte også holde for en Dag, E. T. Kr. var i Besøg på Nørremølle. Endvidere besøgte han $\mathrm{N}$ is $\mathrm{Ca} l$ les e $\mathrm{n}$ i Lerskov og udspurgte en Del Folk i Øster Logumegnen. - I 1901 foretog Fvald Tang Kristensen igen en større Indsamlingsrejse i Sønderjylland. Denne Gang var Ribe Udgangspunktet. Skærbæk var den første $B y$, han gjorde Iloldt i. Her måtte især Peter T i m mer $\mathrm{man} \mathrm{n}$ ud med sin Viden. Derfra gik Turen til Mjolden, Randerup, Trøjborg, Visby, Daler, Møgeltønder, Brede og Løgumkloster. I alle disse Byer gjorde han en god Fangst. - Ar 1902 gik Turen atter sydpå ned midt i Landet. I Københoved besøgte E. T. Kr. Kloppenborg - Skrumsager, i Gram udspurgtes Pastor J o han Z erlang og Frue, der fortalte flere gode Ting, ligesom den gamle fhv. Gabøl- 
Larer Lar s Norga a r d ogsá blev godt udspurgt. I Oster Lindet hos Oluf $\mathrm{H} ø$ yer kom Tang Kristensen i ret heftig Disput med $\mathrm{Kr}$ is t i a $\mathrm{H}$ ø y er, (ler kritiserede hans Indsamling. Den gamle E 1 le $\mathbf{n}$ $B$ e $\left(h^{\prime}\right)$ var ellers den bedste Meddeler i Øster Linlet, men hun kunde ikke synge, så Grüner Nielsen fik ingen Melodier hos hende, da han var der i 1909. Videre gik Turen til Studsbøl, Sommersted, Haderslev, Løjt, Barsinark, Abenrå, Varnæs, Rinkenæs, Flensborg og Froslev. Derefter rejste E. T. Kr. Vest på til Rørkær ved Tønder, hvor Udbyttet blev særlig godt. I Visby og Tønder optegnede han også Folkeminder. Denne Rejse havde i det hele taget givet et godt Udbytte, sả Tang Kristensen fik "godt Mod paa igen at komme ned til Sønderjylland, hvor Folk $i$ det hele var venlige imod mig og meget meddelsomme." - 1903 samlede han Folkeminder $\mathbf{i}$ følgende Byer: Brøns, Skærbæk, Visby, Rørkær, paa Gaarden Ravnholt, Gram, skjoldager, Gabol, Xrderup, Rurup, Tirslund, Branderup, Agerskov; derfra til Ảbenrå, hvorfra Rejser foretoges til Barsmark, og denne Sønderjyllandstur sluttede med rigeligt Udbytte i Haderslev. I 1904 vilde E. Tang Kristensen til ostligere Egne og begyndte i Anslet, tog derfra sydpå til Peder Sk a paa Bukshave. I Fjelstrup blev mange ældre Folk udspurgt. Derfra gik Rejsen til Haderslev, Rurup, Roost, Gram, Ørderup og Ábenrå. 1906 gik Ruten over Sommersted til Haderslev, senere til Gram og Skjoldager, Brendstrup, Ábenrå og Stubbæk. Dernæst tog han ud til Karl A dserse n i Lydersholm i Burkal Sogn. Adsersen "var en udmærket Kilde at øse af«. Blandt de Sjældenheder

1) Billeder af hende og hendes gamle Hus findes i $\mathrm{E}$. Tang Kristensens Hog: "Gamle Kildevald" (1927), $100 \mathrm{f}$. 
han ejede, var et Apparat til at slå en Tyvs Øje ud med. Efter at have tilbragt et Par fornøjelige og oplysende Dage i Lydersholm gik E. T. Kr. til Rørkær, derfra til Visby. - Den sidste Indsamlingsrejse E. T. Kr. foretog i Sønderjylland var i 1910. Den gik til Abenrå, Løjtkirkeby, Ulkebøl, Vollerup, Lysabild. I Hostrup fik han en Del at vide om den synske Frøken Fanny, og hos Karl Adsersen var Udbyttet igen godt. I Øster-Abølling i Roager Sogn besøgtes Lærer M. J. Sk ov. Fra Øster Abølling drog E. T. Kr. til T h øs te $\mathrm{T}$ høs tese $n$ i Fæsted og sluttede sin Rejse hos Uhrmager A. J. M a r c us s e n i Rødding. $\left.{ }^{1}\right)$

I denne korte Redegørelse for E. Tang Kristensens sønderjydske Rejser er nævnt Navne på de Byer, han besøgte og hvor han altså har optegnet Folkeminder. Ligeledes er nævnt Navnene på en Del Mennesker, der på flere Områder har ydet værdifulde Bidrag til sønderjydsk Hjemstavnshistorie, især H. P. Hanssen, Jørgen Fausbøl, Nis Callesen, Kristian Høyer, Johan Zerlang, Lars Nørgaard, Thøste Thøstesen og A. J. Marcussen.

Evald Tang Kristensen fortæller et Sted, ${ }^{2}$ ) at han havde stor Lyst til at udgive en sønderjydsk Sagnsamling, da han på sine Rejser i Sønderjylland havde hørt flere udtale, at de gerne vilde have sådan en Samling, men det blev ikke til noget, måske fordi Axel Olrik rådede ham fra det. Han syntes ikke, de sønderjydske Sagn skulde plukkes fra E. T. Kr.'s andre Sagn.

Den righoldige danske og tyske Literatur om Sønderjyllands Folkeliv og Folketro m. v. findes der

1) Evald Tang Kristensen: "Minder og Oplevelserc IV (1928), 41 ff., 222 ff., 248 ff., 273 ff., 294 ff., 328 ff., 388 ff.

2) Minder og Oplevelser IV 303. 
fyldestgørende Oplysninger om i $\mathrm{H}$. Grü n e r N i els e n instruktive Afhandling: "Sønderjydske Folkeminder" (i Fortid og Nutid III 1920), der indeholder alle nødvendige Oplysninger om Emnet. Siden 1920 er der fremkommet ikke så fả Bøger, Afhandlinger og Artikler om sønderjydsk Folkeliv og Folketro, dels i sønderjydske Årbøger, Sønderjydsk Månedsskrift, Dagblade o. a. Steder, dels i selvstæendige Bøger') af P. Andresen, (dod 1925), He n rik UTs ing, H. P. Hanssen, J. Raben, H. Laust e $n$ Thom sen (Tønder-Bogen 1926), P. E li as s en (død 1928) o. fl.

Det må oprigtigt onskes, at der $\mathrm{i}$ de kommende Ar må blive indsamlet mange Folkeminder i Sønderjylland og fremkomme talrige Arbejder om søncierjydsk Folkeliv og Folketro.

1) Jfr. Fortid og Nutid VI, 84, 313. VII, 83 f., 96, 255. 